\title{
PENGEMBANGAN MODEL PEMBELAJARAN MITIGASI BENCANA GUNUNG MELETUS DI SEKOLAH DASAR LERENG GUNUNG SLAMET
}

\author{
Agung Nugroho ${ }^{1}$ \\ ${ }^{1}$ Prodi PGSD FKIP, Universitas Muhammadiyah Purwokerto \\ Email: agungnugroho@ump.ac.id
}

\begin{abstract}
ABSTRAK
Keberadaan gunung api di Indonesia merupakan akibat dari posisi Indonesia yang terletak pada pertemuan empat lempeng tektonik yaitu lempeng Benua Asia, Australia, lempeng Samudera Hindia dan Samudera Pasifik. Letusan gunung api adalah salah satu sumber bencana yang sering menimbulkan banyak korban dan kerugian. Gunung Slamet merupakan gunung api aktif tertinggi di Provinsi Jawa Tengah dengan aktivitas vulkanik yang tinggi. BNPB (2014) menyebutkan bahwa pada periode 1-11 Agustus 2014 tercatat 474 gempa letusan atau sekitar 43 kejadian/hari, 5.070 kali gempa hempusan atau 456 kejadian perhari. Secara administratif Gunung Slamet melingkupi Kabupaten Pemalang, Banyumas, Brebes, Tegal, dan Purbalingga dengan sejumlah permukiman yang tersebar disekitarnya. Melihat kondisi tersebut sangat diperlukan pemahaman dan pengetahuan akan mitigasi bencana oleh masyarakat disekitar wilayah rawan bencana. Pelatihan mitigasi bencana dilaksanakan di SD Negeri 4 Kotayasa Kecamatan Sumbang yang terletak di wilayah rawan bencana. Pelatihan mitigasi bencana ini dilaksanakan untuk membangun kesadaran guru dan siswa terhadap bencana gunungapi dan memberikan pengalaman mitigasi bencana serta pemahaman saintifik fenomena alam tersebut. Tindak lanjut dari pelatihan ini diharapkan para guru bisa menularkan dan mengajarkan pendidikan kebencaanaan kepada siswa ke dalam pembelajran di kelas sehingga nantinya generasi-generasi kedepan memiliki pengetahuan dan keterampilan dalam menghadapi bencana alam.
\end{abstract}

Kata Kunci: model pembelajaran, mitigasi bencana, gunung meletus

\section{ABSTRACT}

The existence of the volcano in Indonesia is a result of indonesia position located in the four plate tectonic plates the asian continent, australia, plate the indian ocean plate and pacific plate. Volcanic eruption is one of the disaster often generates many of the and loss. Mount Slamet is the volcano active highest in the province of central java with volcanic activity high. BNPB (2014) mentioned that in the period 1-11 August 2014 recorded 474 earthquake eruption or 43 scene per day, 5.070 times earthquake hempusan or 456 scene per day. Administratively mount Slamet protects Pemalang, Banyumas, Brebes, Tegal, and Purbalingga with some settlement scattered around. Seeing this condition indispensable understanding and knowledge of disaster mitigation by the community around proneness. Disaster mitigation training in SD Negeri 4 kotayasa, Sumbang located in areas that are prone to catastrophic. Disaster mitigation training was held to raise awareness of teachers and students for disasters and disaster mitigation volcano lessons as well as the awareness rendering the natural phenomena. A follow-up to this training hopefully teachers can transmitting and teaches kebencaanaan education to students into pembelajran in the class so that the upcoming generations fore having knowledge and skill in handling the disaster

Key word: learning model, disaster mitigation, volcano eruption 


\section{PENDAHULUAN}

Indonesia secara geografis merupakan negara kepulauan yang terletak pada pertemuan empat lempeng tektonik yaitu lempeng Benua Asia, Benua Australia, lempeng Samudera Hindia dan Samudera Pasifik. Pertemuan lempeng inilah yang menyebabkan indonesia memiliki banyak gunung api sehingga menjadi salah satu negara rawan bencana. Berada di jalur cincin api ring of fire Indonesia merupakan negara dengan jumlah gunung api aktif terbesar di dunia dengan memiliki 130 gunung api aktif atau $16 \%$ dari jumlah gunung api di dunia. Gunung Slamet merupakan gunung tertinggi di Provinsi Jawa Tengah dengan aktivitas vulkanik yang tinggi. BNPB (2014) menyebutkan bahwa pada periode 1-11 Agustus 2014 tercatat 474 gempa letusan atau sekitar 43 kejadian/hari, 5.070 kali gempa hempusan atau 456 kejadian perhari. Secara administratif Gunung Slamet melingkupi Kabupaten Pemalang, Banyumas, Brebes, Tegal, dan Purbalingga dengan sejumlah permukiman yang tersebar di sekitarnya. Beberapa dari wilayah permukiman termasuk zona rawan bencana gunung api dengan radius $5 \mathrm{~km}$ dari puncak gunung. Kondisi ini menjadikan pemahaman dan pegetahuan masyarakat indonesia khususnya masyarakat lereng gunung Slamet akan mitigasi bencana sangat penting

Peristiwa bencana yang selama ini terjadi lebih sering disebabkan kurangnya kesadaran dan pemahaman pemerintah maupun masyarakat terhadap potensi kerentanan bencana serta upaya mitigasinya. Mitigasi merupakan bagian kegiatan dari pra bencana, pra bencana ini merupakan bagian dari kegiatan siklus manajemen bencana. Kegiatan pra bencana inilah yang sering dilupakan, padahal justru kegiatan pada pra bencana ini sangat penting karena apa yang sudah dipersiapkan pada tahap ini merupakan modal dalam menghadapi bencana dan pasca bencana.

Mitigasi adalah suatu tahapan yang bertujuan untuk mengurangi kemungkinan dampak negatif kejadian bencana terhadap kehidupan atau dapat diartikan bahwa mitigasi sebagai mengambil tindakan-tindakan untuk mengurangi pengaruh-pengaruh dari suatu bahaya sebelum bahaya terjadi (Rahmat dalam Nirmalawati, 2011:2). Sedangkan bencana sendiri adalah keadaan yang mengganggu kehidupan sosial ekonomi masyarakat yang disebabkan oleh gejala alam atau perbuatan manusia. Bencana dapat terjadi melalui suatu proses yang panjang atau situasi tertentu dalam waktu yang sangat cepat tanpa adanya tandatanda (Fidel dalam Nirmalawati, 2011:2).

Pemahaman mitigasi bencana pada siswa pendidikan dasar merupakan salah satu solusi yang perlu dilakukan di Indonesia, guna mengurangi terjadinya bencana yang mengakibatkan kematian dan kecelakaan pada anak-anak di bawah umur 15 tahun. Jumlah kematian anak-anak yang sangat tinggi serta mengalami stress dan trauma sebenarnya kesemua ini tidak akan terjadi, apabila dari awal anak-anak dibentuk dengan memiliki konsep diri positif dalam memahami mitigasi bencana. Anak-anak yang memiliki pengetahuan tentang cara penyelamatan diri dalam menghadapi bahaya, akan menjadi lebih mampu dan memiliki kepercayaan diri yang positif tanpa merasa ketakutan dan stress (Nirmalawati, 2011:2).

Letusan gunung api adalah salah satu sumber bencana yang sering menimbulkan banyak korban dan kerugian. Pulau Jawa yang dihuni lebih dari $60 \%$ penduduk Indonesia memiliki gunung api tidak kurang 25 buah. Dilihat dari segi ancaman bencana merupakan daerah yang rawan bukan saja dari jenis sumbernya bencana tetapi juga dari kondisi lingkungan dan kependudukannya. Letusan gunung api biasanya disertai oleh semburan abu, pasir, kerikil, batu-batuan, gas dan kadang-kadang juga lahar yang memiliki daya perusak yang tinggi. Hal ini terjadi jika ada bagian dinding bawah yang terbelah dan terdapat muatan 
air bervolume tinggi. Semburan material yang dikeluarkan dari kepundan dapat mencapai ribuan meter dan dapat mengangu lau lintas udara dengan sebaran yang cukup luas. Ancaman bencana oleh letusan gunung api ini dapat meningkat jika masyarakat daerah yang terancam tidak melakukan ketidaksiapsiagaan, demikian juga bila kondisi lingkungan alam telah kehilangan daya tangkal alaminya.

\section{TINJAUAN PUSTAKA}

\section{Mitigasi Bencana}

Mitigasi didefinisikan sebagai tindakan yang diambil sebelum bencana terjadi dengan tujuan untuk mengurangi atau menghilangkan dampak bencana terhadap masyarakat dan lingkungan (Isnainiati, ---:2). Tujuan mitigasi adalah pengurangan kemungkinan resiko, pengurangan konsekuensi resiko, menghindari resiko, penerimaan resiko, serta transfer, pembagian, atau penyebarluasan resiko.

UU nomor 24 tahun 2007 tentang Penanggulangan Bencana, mendefinisikan mitigasi adalah serangkaian upaya untuk mengurangi risiko bencana, baik melalui pembangunan fisik maupun penyadaran dan peningkatan kemampuan menghadapi ancaman bencana. Lebih lanjut, mitigasi adalah serangkaian upaya untuk mengurangi risiko bencana, baik melalui pembangunan fisik maupun penyadaran dan peningkatan kemampuan menghadapi ancaman bencana (Pasal 1 ayat 6 PP No 21 Tahun 2008 Tentang Penyelenggaraan Penanggulangan Bencana). Menurut Coburn (dalam Sejati 2014: 14) mitigasi adalah istilah yang digunakan untuk menunjuk pada semua tindakan untuk mengurangi dampak dari suatu bencana yang dapat dilakukan sebelum bencana itu terjadi, termasuk kesiapan dan tindakan-tindakan untuk mengurangi resiko-resiko yang terkait dengan bahayabahaya karena ulah manusia dan bahaya alam yang sudah diketahui, dan proses perencanaan untuk respon yang efektif terhadap bencana-bencana yang benar-benar terjadi. Sejalan dengan pendapat di atas, Astuti (dalam Sejati 2014) menyatakan bahwa mitigasi merupakan suatu tindakan yang dilakukan untuk mengurangi dampak yang disebabkan oleh bencana.

Berdasarkan berbagai pandangan tentang mitigasi tersebut dapat disimpulkan bahwa mitigasi adalah serangkaian upaya atau tindakan yang dilakukan membatasi dan mengurangi resiko yang disebabkan dari bencana alam dengan memaksimalkan pembangunan fisik serta peyadaran dalam masyarakat dan pemerintah serta peningkatan kemampuan untuk menghadapi ancaman bencana yang ada dan resiko-resiko dari ulah manusia sendiri.

\section{Pengetahuan Mitigasi Bencana}

Bencana alam yang datang tidak dapat dihindari dan diramalkan secara pasti kapan terjadinya. Namun kerugian dan korban jiwa dapat diminimalisir jumlahnya apabila masyarakat memiliki pengetahuan dan pemahaman akan pentingnya mitigasi bencana. Pendidikan mitigasi bencana penting diberikan khususnya kepada anak-anak yang tinggal di daerah rawan bencana longsor. Pemahaman akan ancaman bencana diharapkan mampu menumbuhkan dampak positif dalam memelihara lingkungan. Selain itu, dengan memiliki karakter tanggap bencana diharapkan dapat mengurangi kerugian dan korban jiwa saat terjadinya bencana. (Hendriyani,2014:2) 
Indonesia, dari berbagai pengalaman menunjukkan belum sanggup melaksanakan penanganan bencana secara profesional, proporsional dan holistik. Saat ini yang ada hanyalah sebatas sporadik dan sesaat saja dan juga dilakukan jika sudah terjadi bencana. Penanganannya hanya sebatas memberi bantuan pada saat tanggap darurat. Untuk itu banyak hal yang bisa digali pada pendidikan kebencanaan di sekolah. Ini dapat dimulai dari tingkat sekolah dasar sampai tingkat sekolah menengah atas. Masyarakat di seluruh dunia sudah memandang bahwa anak anak menghadirkan harapan masa depan. Sekolah mempunyai dampak langsung terhadap generasi muda dan sekolah harus menanamkan nilai nilai budaya dan menyampaikan pengetahuan kepada siswa. Pendidikan kebencanaan di sekolah dasar dan menengah membantu anak anak memainkan peranan penting dalam penyelamatan hidup dan perlindungan anggota masyarakat. Penyelenggaraaan pendidikan tentang resiko bencana kedalam kurikulum sekolah sangat membantu dalam membangun kesadaran akan isu tersebut di lingkungan masyarakat. Peran guru adalah pada pra bencana, sehingga kegiatan pendidikan kebencanaan dapat dilakukan dengan terencana, terarah, terstruktur dan terukur. Siswa dapat dididik dengan karakter tanggap bencana dan karakter memperlakukan alam dengan baik dan benar. (Honesti, 2012:5).

Pendidikan bencana merupakan proses pembelajaran melalui penyediaan informasi, pengetahuan, dan kewaspadaan terhadap peserta didik guna membentuk kesiapan bencana di level individu dan komunitas. Melalui pendidikan bencana, peserta didik didorong untuk mengetahui risiko bencana, mengumpulkan informasi terkait mitigasi bencana, dan menerapkannya pada situasi bencana (Shiwaku et al., 2007). Setiap unit kerja atau instansi berkewajiban menfasilitasi penghuni dengan pendidikan bencana untuk memastikan bahwa tindakan yang tepat akan dilakukan saat bencana terjadi. Pendidikan bencana dapat diwujudkan melalui kurikulum pendidikan, pelatihan, dan simulasi bencana.

Penelitian terhadap pentingnya pendidikan bencana pernah dilakukan oleh Shaw dalam Shiwaku et al. (2004, 2007) terhadap 452 siswa di Kathmandu, Nepal. Hasil penelitian ini menjelaskan bahwa komunitas memiliki peranan penting terhadap kewaspadaan dan kesiapan bencana pada siswa sehingga anggota komunitas perlu dilibatkan pada pendidikan bencana di sekolah. Pendidikan bencana tidak hanya cukup diberikan di sekolah, tetapi juga perlu dipromosikan kepada keluarga dan komunitas. Peserta didik yang telah mendapatkan pendidikan bencana diharapkan mampu mengajarkan pada anggota keluarga di rumah dan komunitas sekitar sehingga kesiapan bencana di level komunitas terbentuk.

\section{BAHAN DAN METODE}

Kegiatan dilaksanakan pada bulan Februari 2017 bekerjasama dengan SD Negeri 4 Kotayasa Kecamatan Sumbang Kabupaten Banyumas yang merupakan kawasan dengan radius rawan bencana alam gunung Slamet. Pengembangan model pembelajaran mitigasi bencana gunung meletus ini disusun dengan pendekatan partisipatif dengan mengoptimalkan peran seluruh warga sekolah yang meliputi kepala sekolah, guru serta siswa kelas 5. Model yang dikembangkan yaitu simulasi bencana berbantu media poster, komik dan video pembelajaran. Bahan yang digunakan dalam pelatihan ini yaitu media komik dan poster.

\section{HASIL DAN PEMBAHASAN}

\section{Pendidikan mitigasi untuk membangun masyarakat sadar bencana}


Mitigasi didefinisikan sebagai upaya yang ditujukan untuk mengurangi dampak dari bencana baik bencana alam, bencana ulah manusia maupun gabungan dari keduanya dalam suatu negara atau masyarakat Tujuan dari mitigasi yaitu mengurangi risiko dan dampak yang diakibatkan oleh bencana terhadap masyarakat yang berada pada kawasan rawan bencana. (PP no 21 2008).

Realisasi penyelesaian permasalahan ini yaitu dengan melakukan pelatihan mtitigasi bencana memlalui media poster, komik dan simulasi. Simulasi menjadi metode yang sangat cocok diterapkan pada masayarakat rawan bencana. Simulasi yaitu metode pembelajaran atau pendampingan yang memperagakan dalam bentuk tiruan yang mirip dengan keadaan yang sesungguhnya. Metode ini mempergunakan gambaran dari situasi yang nyata tanpa harus mengalaminya.

Simulasi berasal dari kata simulate yg artinya berpura-pura atau berbuat seakan-akan. Metode pembelajaran atau pendampingan yang memperagakan dalam bentuk tiruan yang mirip dengan keadaan yg sesungguhnya. Metode ini memperagakan/mempergunakan gambaran dari situasi yang nyata tanpa harus mengalaminya. Jenis simulasi: sosiodrama, psikodrama, role playing, peer teaching, simulasi game, mitigasi.

Tujuan dari simulasi diantaranya :

- Menambah pengetahuan serta wawasan masyarakat tentang penaggulangan bencana

- Membantu masyarakat memahami tat cara penanggulangan bencana

- Membantu masyarakat memahami teknik evakuasi dalam situasi bencana

- Melatih dan membiasakan masyarakat untuk siap siaga (tidak panik)

- Menjadi sarana latihan dan praktek dalam usaha penanggulangan bencana

Pengetahuan mitigasi bencana sejak dini mutlak dibutuhkan oleh siswa. Guru memiliki peran penting dalam memberikan pengetahuan dan keterampilan kesiapsiagaan menghadapi bencana pada para peserta didik. Pelatihan ini sangat diperlukan oleh guru sebagai tenaga pendidik yang dalam keseharinnya berinterkasi langsung dengan siswa. Dengan kesadaran kebencanaan sejak dini diharapkan kedepan nantinya Indonesia memiliki

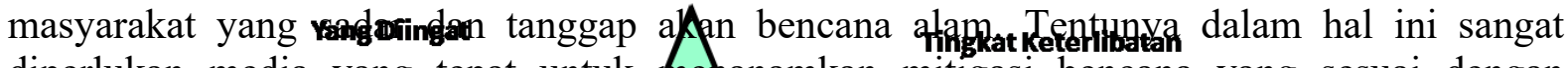
diperlukan media ${ }_{10}$ \%ang tepat untuk nexanamkan mitigasi bencana yang sesuai dengan kebutuhan dan karakteristik siswa. Pfhamalpan mitigasi bencana sejak dini di sekolah dapat dilakukan dengan 29\%entggunakan bantwengreantita bergambar, Yethlan simulasi ringan, maupun menyisipkan materi mitigasi beprcan ainhinadolan materi pelajardn yang sesuai. Pemberdayaan anak sejak dini untuk memahani piantras bencana merypakan langkah awal dalam membangun masyarakat sad r benthatradeo/Fengan harapan pongetahuan yang didapat dari sekolah dapat ditularkan padæl lingkungan sekitar falam rangkisufflengurangi risiko bencana.

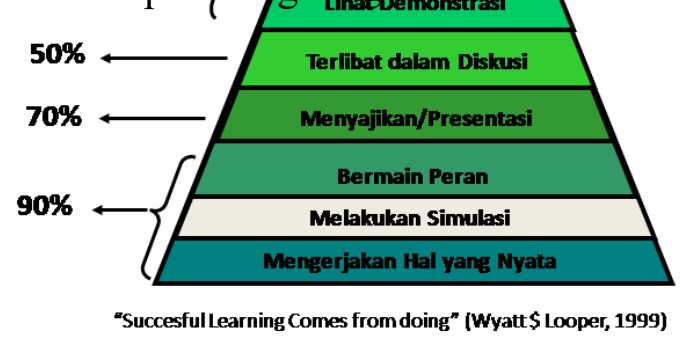

Terlibat

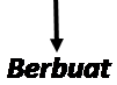


Kerucut pengalaman belajar Edgar Dale

Pendidikan mitigasi bencana pada guru dapat dilakukan dengan beragam model atau pendekatan dalam pembelajaran. Media poster, video dan komik merupakan media yang sangat sesuai dalam meningkatakan pemahaman siswa khususnya materi pendidikan bencana. Hal ini sesuai dengan teoeri kerucut pengalam dari Edgar Dale. Teori ini menjelaskan bahwa tingkat keterlibatan siswa melalui pendekatan yang besrsifat verbal, visual, terlibat dan berbuata memiliki pengaruh yang berbeda terhadap pemahaman dan daya ingat siswa.harapan kedepan bahwa pelatihan ini tidak berhenti namun guru diharapkan memiliki keterampilan dalam mengajarkan pendidikan mitigasi bencana kepada siswa sejak dini melalui intergrasi dalam pembelajaran di kelas secara continue dan berkesinambungan dari generasi ke generasi sehingga akan tercipta masyarakat yang memiliki pendidikan bencana dan kesadaran tanggap bencana.
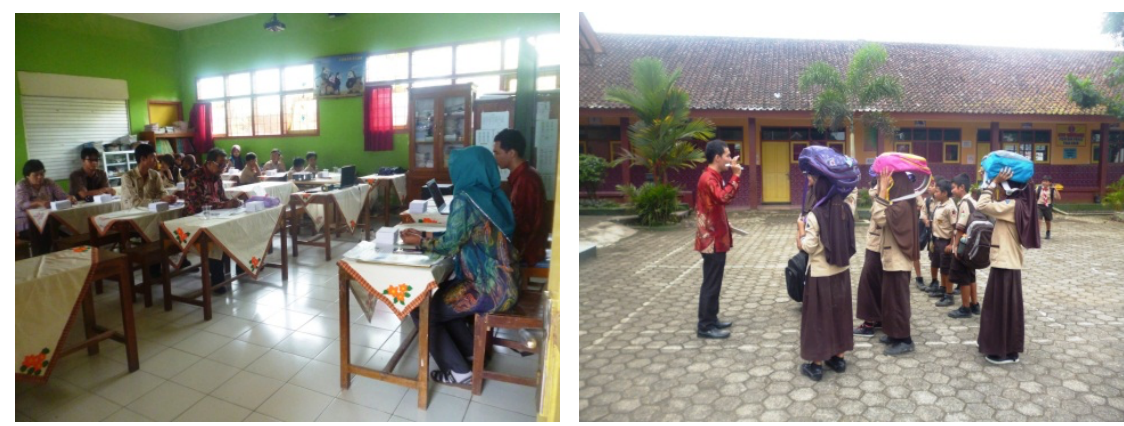

Gambar diskusi dan simulasi mitigasi bencana

\section{Implementasi dalam proses pembelajaran}

Pendidikan untuk mengurangi resiko akibat bencana sangat penting dan perlu disosialisasikan pada masyarakat agar korban saat terjadi bencana dapat diminimalkan. Sosialisasi pendidikan mitigasi bencana sejak dini dapat dilakukan di sekolah dasar melalui metode yang tepat. Sebagai contoh di Jepang pendidikan bencana sudah masuk ke dalam kurikulum pendidikan di semua jenjang sehingga masyarakat memiliki kesadaran tanggap bencana yang tinggi sejak dini. Guru sebagai pendidik yang berinterkasi langsung dengan siswa mempunyai peran yang strategis untuk mensosialisasikan pendidikan mitigasi bencana. Guru diharapkan memiliki keterampilan mitigasi bencana yang nantinya diajarkan kepada siswa. Rendahnya kesadaran tanggap bencana masyrakat Indonesia khusunya di daerah rawan bencana menjadi masalah serius mengingat kondisi wilayah indonesai sendiri yang rawan berbagai bencana alam. Kurangnya kesadran tanggap bencana mengakibatkan banyaknya jumlah korban ketika terjadi bencana. Kedepan, para guru hrus bisa menularkan dan mengajarkan pendidikan kebencaanaan kepada siswa ke dalam pembelajran di kelas sehingga nantinya generasi-generasi kedepan memiliki pengetahuan dan keterampilan dalam menghadapi bencana alam. 


\section{KESIMPULAN}

Kegiatan pelatihan mitigasi bencana gunung api SD Negeri 4 Kotayasa dapat membangun kesadaran siswa dan guru dalam menghadapi bencana gunungapi Slamet yang mungkin terjadi. Proses dan tahapan pelaksanaan kegiatan pelatihan mengacu pada standar pelatihan mitigasi yang memfokuskan pada kemandirian dan pengalaman peserta didik. Pelatihan mitigasi bencana menggunakan media poster, komik dan simulasi diharapkan akan memberikan keterampilan dan pengetahuan mitigasi bencana bagi guru dalam rangka membentuk masyarakat siaga bencana.

\section{DAFTAR PUSTAKA}

BNPB. 2014. Info Bencana. Buletin Edisi Agustus 2014. Diunduh dari : http://bnpb.go.id/uploads/publication/1056/info_bencana_Agustus_2014.pdf

Hendriyani, Serlia. Sowiyah, Mugiadi. 2014. Model Exclusive Dengan Metode Permainan Untuk Meningkatkan Kompetensi Mitigasi Longsor. Bandar Lampung; Universitas Lampung.

Honesti , Leli. Djali, Nazwar. 2012. Pendidikan Kebencanaan Di Sekolah - Sekolah Di Indonesia Berdasarkan Beberapa Sudut Pandang Disiplin Ilmu Pengetahuan. Jurnal Momentum. Universitas Bung Hatta.

Isnainiati, Nur dkk. ------. Artikel. Kajian Mitigasi Bencana Erupsi Gunung Merapi Di Kecamatan Cangkringan Kabupaten Sleman. Semarang: UNDIP.

Nirmalawati. 2011. Pembentukan Konsep Diri pada Siswa Pendidikan Dasar dalam Memahami Mitigasi Bencana. Jurnal SMARTek, Vol. 9 No. 1. Pebruari 2011: 61 69. Universitas Tadulako : Palu.

Peraturan Pemerintah Republik Indonesia Nomor 21 tahun 2008 Tentang Penyelenggaraan Penanggulangan Bencana.

Undang-Undang no. 24 Tahun 2007 tentang Penanggulangan Bencana

Sejati, Prajana Marwan. 2015.. Pengembangan Buku Teks Tentang Mitigasi Bencana Erupsi Gunung Api Dalam Pembelajaran Ipa Kelas Iv Sd Negeri Kiyaran 2 Sleman Yogyakarta. Skripsi UNY.

Shiwaku, Koichi et al. (2007). Future perspective of school disaster education in Nepal.

Journal of Disaster Prevention and Management. Emerald Group Publishing, 16, (4), 2-10 